\title{
„DOMNIEMANIE WINY” W PRAWIE KARNYM MATERIALNYM A PROCESOWE DOMNIEMANIE NIEWINNOŚCI
}

\section{PROBLEM BADAWCZY STANOWIĄCY PRZEDMIOT OPRACOWANIA}

Artykuł 5 § 1 k.p.k. wyraża zasadę domniemania niewinności, w myśl której „oskarżonego uważa się za niewinnego, dopóki wina jego nie zostanie udowodniona i stwierdzona prawomocnym wyrokiem”. Domniemanie niewinności ma charakter formalny, nakaz traktowania oskarżonego jak osoby niewinnej aktualizuje się bowiem bez potrzeby udowadniania podstawy domniemania, oraz wzruszalny, ponieważ domniemanie upada wskutek prawomocnego stwierdzenia winy oskarżonego ${ }^{1}$. W literaturze wskazuje się, że przepis ten wyraża „prawdę tymczasowa”, zgodnie z którą oskarżony jest niewinny do czasu prawomocnego rozstrzygnięcia postępowania. W przypadku uniewinnienia, ewentualnie umorzenia postępowania po postawieniu zarzutów, „prawda tymczasowa" nabiera cech trwałości, a domniemanie niewinności staje się niewzruszalne. Jeżeli sąd prawomocnie stwierdzi winę - domniemanie niewinności upada ${ }^{2}$. W prawie procesowym zakłada się prawidłowość prawomocnego wyroku skazującego, a w konsekwencji domniemywa się winy skazanego ${ }^{3}$, które to domniemanie może zostać wzruszone wskutek uwzględnienia nadzwyczajnych środków zaskarżenia ${ }^{4}$.

W prawie karnym domniemanie winy pojawia się także w innym kontekście. Przedstawiciele nauki prawa karnego materialnego, analizując sposób sformułowania art. 1 k.k., konstruującego strukturę przestępstwa, wskazuja, że $\S 3$ tego przepisu ujmuje warunek zawinienia od strony negatywnej. Sta-

${ }^{1}$ Zob. P. Kruszyński, S. Pawelec, Zasada domniemania niewinności, w: P. Wiliński (red.), System prawa karnego procesowego. Zasady procesu karnego, t. 2, cz. 2, Warszawa 2014, s. 16101611; P. Kruszyński, Zasada domniemania niewinności w polskim procesie karnym, Warszawa 1983, s. 44-45. Odmienny pogląd, że podstawą domniemania jest brak prawomocnego wyroku skazującego lub warunkowo umarzającego postępowanie, wyraziła A. Tęcza-Paciorek, Zasada domniemania niewinności w polskim procesie karnym, Warszawa 2012, s. 63.

2 T. Grzegorczyk, J. Tylman, Polskie postępowanie karne, Warszawa 1998, s. 126; A. Tęcza-Paciorek, op. cit., s. 58.

${ }^{3}$ M. Cieślak, Zagadnienia dowodowe $w$ procesie karnym, t. 1, Warszawa 1955, s. 177; P. Kruszyński, S. Pawelec, op. cit., s. 1637.

${ }^{4}$ Ibidem, a także A. Tęcza-Paciorek, op. cit., s. 58. 
nowi on, że: „Nie popełnia przestępstwa sprawca czynu zabronionego, jeżeli nie można mu przypisać winy w czasie czynu". Co istotne, pierwotny projekt Kodeksu karnego ujmował tę przesłankę od strony pozytywnej. Przeto twierdzi się, że taki sposób sformułowania przepisu nie jest przypadkowy. U jego podstaw leży pogląd ustawodawcy, że co do zasady człowiek ponosi odpowiedzialność za swoje czyny, iż jest w stanie sensownie autodeterminować swoje zachowanie i dochować wierności prawu. Pogląd ten znajduje uzasadnienie w przekonaniu o godności człowieka, w traktowaniu ludzi podmiotowo, a nie przedmiotowo, jako istot zdolnych do pokierowania swoim zachowaniem i ponoszenia konsekwencji dokonywanych wyborów ${ }^{5}$. Dlatego w procesie nie udowadnia się wolności oskarżonego w trakcie popełniania czynu, jego zdolności do sensownego pokierowania swoim zachowaniem, lecz zajście okoliczności wyłączajacych winę, takich jak np. choroba psychiczna oskarżonego skutkująca jego niepoczytalnością. Co więcej, przypadki, w których sprawcy czynu zabronionego nie będzie można przypisać winy, należą do rzadkości, stanowia wyjątek od reguły. Konieczność prowadzenia dowodu w tym zakresie, np. co do niepoczytalności oskarżonego, pojawi się tylko wówczas, gdy organ poweźmie wątpliwość ${ }^{6}$. Stąd twierdzi się, że w prawie karnym materialnym obowiązuje zasada domniemania winy ${ }^{7}$.

Pojawia się pytanie o szczegółowe konsekwencje wynikające z domniemywania winy $\mathrm{w}$ prawie karnym materialnym oraz o relację pomiędzy tym domniemaniem a procesowym domniemaniem niewinności.

\section{POJĘCIE WINY W PRAWIE KARNYM MATERIALNYM ORAZ W PRAWIE KARNYM PROCESOWYM}

W pierwszej kolejności należy wyjaśnić, w jakim znaczeniu posłużono się terminem „wina” w art. $1 \S 3$ k.k., a w jakim w art. $5 \S 1$ k.p.k. W prawie karnym materialnym wina jest jednym $\mathrm{z}$ elementów struktury przestępstwa, obok bezprawności, karalności i karygodności ${ }^{8}$. Wymóg przypisania winy sprawcy czynu zabronionego zapewnia subiektywizację odpowiedzialności

${ }^{5}$ Zob. W. Wróbel, O domniemaniach w zakresie przestanek odpowiedzialności karnej, „Prace Instytutu Prawa Własności Intelektualnej UJ”, nr 96, 2006, s. 247; idem, Wina i zawinienie a strona podmiotowa czynu zabronionego, czyli o potrzebie postugiwania się $w$ prawie karnym pojęciem winy umyślnej i nieumyślnej, w: J. Giezek (red.), Przestępstwo kara polityka kryminalna. Problemy tworzenia i funkcjonowania prawa. Ksiega jubileuszowa z okazji 70. rocznicy urodzin Profesora Tomasza Kaczmarka, Kraków 2006, s. 678-680.

${ }^{6}$ Powyższa okoliczność od dawna jest dostrzegana w literaturze procesowej. Zob. M. Cieślak, op. cit., s. 148-149; J. Nelken, Domniemania w procesie karnym, „Nowe Prawo” 11, 1970, s. 1604.

7 Zob. J. Lachowski, w: R. Dębski, System prawa karnego. Nauka o przestęstwie. Zasady odpowiedzialności, Warszawa 2013, s. 659 i 664; T. Kaczmarek, Spory wokót pojęcia winy, w: L. Leszczyński, E. Skrętowicz, Z. Hołda (red.), W kręgu teorii i praktyki prawa karnego: księga poświęcona pamięci Profesora Andrzeja Waska, Lublin 2005, s. 194; W. Wróbel, A. Zoll, Polskie prawo karne, Kraków 2013, s. 330. Z tego powodu za nieprecyzyjne należy uznać stwierdzenie, że domniemanie winy ma wyłącznie charakter historyczny. Zob. P. Kruszyński, S. Pawelec, op. cit., s. 1584.

${ }^{8}$ W. Wróbel, A. Zoll, op. cit., s. 179. 
karnej i ogranicza stosowanie represji karnej jedynie do przypadków, w których osoba pociagana do odpowiedzialności mogła dać posłuch prawu ${ }^{9}$.

Pewne trudności w precyzyjnym określeniu przedmiotu domniemania w prawie karnym materialnym sprawia brak jednomyślności co do natury winy jako przesłanki przestępczości czynu. We współczesnej nauce prawa karnego konkurują ze sobą dwie normatywne teorie winy: kompleksowa i czysta. Wedle pierwszej wina jest „zarzucalną umyślnością lub nieumyślnościa”, na jej treść składają się przeżycia psychiczne (umyślność/nieumyślność), które warunkuja, po spełnieniu innych przesłanek, negatywną ocenę czynu (zarzut). Wedle drugiej wina jest wyłącznie „sądem wartościującym”, zarzutem z powodu umyślności lub nieumyślności, natomiast same przeżycia psychiczne nie składaja się na jej pojęcie ${ }^{10}$. Przyjęcie pierwszej koncepcji uprawniałoby do postawienia tezy, że domniemaniem objęte są zarówno umyślność/nieumyślność, jak i zachodzenie innych okoliczności umożliwiających postawienie zarzutu. Opowiedzenie się za drugą oznacza, że domniemaniem jest objęte jedynie zachodzenie owych innych okoliczności. Przedmiot domniemania byłby więc ujęty znacznie węziej. Należy jednak zaznaczyć, że na gruncie przepisów Kodeksu karnego z 1997 r. nawet zwolennicy koncepcji kompleksowej godza się z podwójnym usytuowaniem umyślności/nieumyślności w strukturze przestępstwa: stanowią one także stronę podmiotową czynu zabronionego, należą do jego znamion ${ }^{11}$. A ponieważ przesłanka popełnienia czynu zabronionego jest w art. $1 \S 1 \mathrm{k} . \mathrm{k}$. ujęta od strony pozytywnej, a w $\S 3$ tego przepisu mowa o sprawcy czynu zabronionego, umyślności/nieumyślności, mimo że składaja się na pojęcie winy, nie można domniemywać w oparciu o to ostatnie postanowienie $^{12}$.

Na gruncie prawa karnego procesowego wina ma odmienne znaczenie. Lech Gardocki twierdzi, że „w prawie karnym procesowym posługujemy się szerokim pojęciem winy [...] wina jest tu sumą przesłanek, które musza być spełnione, by sprawca mógł ponieść odpowiedzialność karną. Ustalając, że oskarżony jest winien, stwierdzamy, że to właśnie on jest sprawcą danego czynu, że czyn ten jest przestępstwem, że jest bezprawny, że między zachowaniem się sprawcy a skutkiem zachodzi zwiąek przyczynowy, że sprawca działał umyślnie lub nieumyślnie, że był w chwili czynu poczytalny, itd. Można powiedzieć, że prawo karne procesowe posługuje się pojęciem winy zaczerpniętym z języka potocznego"13. W konsekwencji na gruncie prawa procesowego przyjmuje się, że termin „wina” odnosi się do podstawy odpowiedzialności karnej, a więc oznacza zachodzenie wszystkich jej przesłanek, nie tylko winy w rozumieniu prawa karnego materialnego, ale także sprawstwa czynu zabronionego, jego bezprawności i karygodności ${ }^{14}$.

${ }^{9}$ D. Świecki, Wina $w$ prawie karnym materialnym i procesowym, „Prokuratura i Prawo” 2009, nr 11-12, s. 6.

${ }_{10}$ Zob. J. Lachowski, op. cit., s. 630-642; T. Kaczmarek, op. cit., s. 178-186.

${ }^{11}$ Ibidem, s. 186.

${ }^{12}$ Tak, jakkolwiek bez uzasadnienia, J. Lachowski, op. cit., s. 676. Autor wskazuje jedynie, że znamiona strony podmiotowej podlegają udowodnieniu w procesie karnym.

${ }^{13}$ L. Gardocki, Prawo karne, Warszawa 2008, s. 52.

${ }^{14}$ D. Świecki, op. cit., s. 11; W. Wróbel, A. Zoll, op. cit., s. 329. 
Rozważając relację pomiędzy art. $5 \S 1$ k.p.k. a art. $1 \S 3$ k.k., należy mieć na względzie powyższe zamieszanie terminologiczne. W odmiennym przypadku można narazić się na dyskusyjne wnioski, np. Wojciech Patryas z art. $5 \S 1$ k.p.k. wywodzi normę nakazującą sądowi, który przeprowadził postępowanie dowodowe wykazujące, że oskarżony popełnił czyn zabroniony i nie przeprowadził postępowania dowodowego, wykazującego, że oskarżonemu można przypisać winę podczas czynu - aby w wyroku stwierdził, iż oskarżony bez winy popełnił czyn zabroniony ${ }^{15}$. Autor ten ujmuje więc domniemanie niewinności jako domniemanie materialne, a nie formalne, przyjmując za jego podstawę przeprowadzenie postępowania dowodowego wykazującego, że oskarżony jest sprawca czynu zabronionego. Rozumowanie powyższe opiera się na utożsamieniu winy procesowej z winą karnomaterialną i prowadzi do wniosków diametralnie odmiennych od formułowanych w literaturze prawa karnego, w której postuluje się domniemywanie braku sprawstwa czynu zabronionego, a w razie przeprowadzenia przeciwdowodu przyjmuje się domniemanie winy karnomaterialnej.

Odmienne zapatrywanie terminologiczne zaprezentował także Włodzimierz Wróbel, który odróżnił winę od zawinienia. Wina to zarzut stawiany sprawcy z powodu popełnionego przez niego czynu, niosacy za sobą negatywna ocenę tego, co sprawca uczynił. Natomiast zawinienie to zespół okoliczności umożliwiajacych postawienie sprawcy zarzutu. Karnomaterialne domniemanie odnosi się tylko do zawinienia, nie do winy. Nie ma więc podstaw do nadawania terminowi „wina” odmiennego znaczenia w prawie materialnym i procesowym. W obu dziedzinach prawa obowiąuje domniemanie zawinienia czynu przez sprawcę oraz domniemanie niewinności, ponieważ winę oskarżonemu można przypisać dopiero po udowodnieniu mu sprawstwa czynu zabronionego ${ }^{16}$. Ujęcie to sugeruje, że nie ma sprzeczności między domniemywaniem braku winy (niewinności) a domniemywaniem jednej z przesłanek winy, tj. zawinienia. Do poglądu tego przyjdzie nam jeszcze wrócić w dalszej części opracowania. Ponadto powyższe zapatrywanie nie udziela odpowiedzi na pytanie, dlaczego przesłankę winy, zasadzającej się także na sprawstwie czynu zabronionego, ustawodawstwa ują od strony negatywnej, chociaż merytoryczne podstawy takiego zabiegu ograniczały się jedynie do zawinienia.

\section{KONSEKWENCJE UJMOWANIA DOMNIEMANIA ZAWINIENIA JAKO DOMNIEMANIA PRAWNEGO}

Domniemanie może mieć charakter prawny lub faktyczny. W literaturze przedmiotu twierdzi się, że domniemanie prawne jest normą prawną albo że norma prawna leży u podstaw takiego domniemania ${ }^{17}$. Do zakresu zastoso-

15 W. Patryas, Próba wyjaśnienia domniemań prawnych, Poznań 2011, s. 115.

${ }_{16}$ W. Wróbel, Wina $i$ zawinienie..., s. 679-680. Pogląd ten akceptuje J. Lachowski, op. cit., s. 676

${ }^{17}$ Do przedstawicieli pierwszego nurtu należy zaliczyć: J. Wróblewskiego, Domniemania w prawie-problematyka teoretyczna, „Studia Prawno-Ekonomiczne” 10, 1973, s. 10; L. Morawski, Domniemania a dowody prawnicze, Toruń 1981, s. 40, i jak się zdaje J. Nowackiego, Domniemania prawne, Katowice 1976, s. 22. Do przedstawicieli drugiego W. Patryasa, op. cit., s. 79-83. 
wania takiej normy zalicza się określenie jej adresata, okoliczności, w której ma zastosowanie, a w przypadku domniemań materialnych - udowodnienie określonej okoliczności stanowiącej przesłankę domniemania. W zakresie normowania norma nakazuje swojemu adresatowi, aby zachował się tak, jak zachowałby się, gdyby zdania stwierdzające istnienie faktów domniemanych były składnikiem jego wiedzy ${ }^{18}$.

Nie ulega wątpliwości, że procesowe domniemanie niewinności jest domniemaniem prawnym ${ }^{19}$. Należy przyjać, że u jego podstaw leży norma nakazujaca organom procesowym w postępowaniu karnym ${ }^{20}$ do czasu udowodnienia winy i uprawomocnienia się wyroku skazującego lub warunkowo umarzającego postępowanie $^{21}$, aby zachowały się tak, jak zachowałyby się, gdyby składnikiem ich wiedzy było zdanie stwierdzajace, iż oskarżony ${ }^{22}$ jest niewinny ${ }^{23}$. W literaturze przyjmuje się, że konsekwencją obowiązywania powyższej zasady jest nakaz uniewinnienia oskarżonego, ewentualnie umorzenia postępowania, gdy jego wina nie zostanie udowodniona. Uniewinnienie/umorzenie następuje w przypadku nieudowodnienia winy, a nie w przypadku udowodnienia niewinności, w konsekwencji przyjmuje się, że materialny ciężar dowodu spoczywa na oskarżycielu. Oznacza to, że oskarżony ma prawo do zachowania bierności - nie musi udowadniać swojej niewinności, i mimo to nie zostanie obciążony negatywnymi konsekwencjami braku przeprowadzenia dowodu w tym przedmiocie. Konsekwentnie, wszelkie wątpliwości co do winy oskarżonego należy rozstrzygać na jego $\mathrm{rzecz}^{24}$.

W literaturze procesowej, w wypowiedziach odnoszacych się wprost do zasady domniemania niewinności pierwszy nurt reprezentuje W. Daszkiewicz, Proces karny, Warszawa-Poznań 1994, s. 68, drugi - M. Cieślak, op. cit., s. 172, który odróżnia domniemanie rozumiane jako sąd o określonej treści, od normy prawnej, która nakazuje ten sąd przyjąć.

${ }^{18}$ Określenie zachowania stanowiącego przedmiot nakazu jest jednym $\mathrm{z}$ bardziej kontrowersyjnych zagadnień w literaturze. Przyjmuję koncepcję zaproponowaną przez E. Ullman-Margalis. Zob. W. Patryas, op. cit., s. 74. Koncepcje przyjmujące, że nakazane zachowanie polega bądź na uznaniu określonego faktu (J. Wróblewski, op. cit., s. 12), ewentualnie pewnej reguły inferencji materialnej (L. Morawski, op. cit., s. 40), czynią przedmiotem obowiązku procesy myślowe, które z trudem poddają się normowaniu. Ponadto uznaję, że domniemanie prawne nie wiąże się z uznaniem faktu domniemanego za udowodniony, a zdania stwierdzającego istnienie tego faktu za prawdziwe. Zob. J. Nowacki, op. cit., s. 30-31.

${ }^{19}$ P. Kruszyński, S. Pawelec, op. cit., s. 1610.

${ }^{20} \mathrm{~W}$ literaturze wskazuje się, że zasada domniemania niewinności ma swój aspekt procesowy i pozaprocesowy. Istnienie pozaprocesowego aspektu wywodzi się jednak z art. 42 ust. 3 Konstytucji oraz innych przepisów. Zob. ibidem, s. 1634; W. Wróbel, O dwóch aspektach konstytucyjnej zasady domniemania niewinności, w: K. Krajewski (red.), Nauki penalne wobec problemów wspótczesnej przestepczości. Księga jubileuszowa z okazji 70. rocznicy urodzin Profesora Andrzeja Gaberle, Warszawa-Kraków 2007, s. 324; A. Tęcza-Paciorek, op. cit., s. 71-74.

${ }^{21}$ Ibidem, s. 58; P. Kruszyński, S. Pawelec, op. cit., s. 1637-1638. Doprecyzować należy, że w stosunku do niektórych czynności (np. wyrokowanie przez sąd I instancji) nakaz przestaje obowiązywać po udowodnieniu winy, lecz przed uprawomocnieniem wyroku.

${ }^{22}$ Chodzi o oskarżonego sensu largo, a więc także podejrzanego, osobę podejrzaną oraz tzw. faktycznie podejrzany. Zob. P. Kruszyński, S. Pawelec, op. cit., s. 1636.

${ }^{23}$ Co jest zgodne z obiektywistycznym podejściem do zasady domniemania niewinności: organ ma obowiazek nie tyle uważać oskarżonego za osobę niewinna, lecz traktować go jak osobę niewinna. Koncepcja ta dominuje w literaturze. Zob. ibidem, s. 1610.

${ }^{24}$ Prawo do milczenia, onus probandi, reguła in dubio pro reo sa w literaturze traktowane jako konsekwencje bądź komponenty zasady domniemania niewinności. Zob. P. Kruszyński, 
Spróbujmy teraz skonkretyzować obowiąek statuowany przez powyższa normę w sytuacji udowodnienia oskarżonemu sprawstwa czynu i nieprzeprowadzenia dowodu zawinienia (winy w rozumieniu prawa karnego materialnego). W tym miejscu należy wrócić do sugestii, że obowiązek traktowania oskarżonego jak osoby niewinnej (domniemywania jej niewinności) nie oznacza per se obowiązu domniemywania braku zachodzenia poszczególnych przesłanek odpowiedzialności karnej. W tym ujęciu nakaz domniemywania niewinności zostałby przełamany dopiero w przypadku domniemania zachodzenia wszystkich przesłanek przestępczości, co byłoby równoznaczne z domniemywaniem jego winy, nie stałoby natomiast w sprzeczności z tym obowiązkiem domniemywanie zachodzenia tylko niektórych z tych przesłanek. Kwestia zachodzenia pozostałych byłaby otwarta, stąd można byłoby przyjmować, że oskarżony jest niewinny. Pogląd ten należy odrzucić, ponieważ domniemanie niewinności upada jedynie w przypadku udowodnienia oskarżonemu winy w rozumieniu prawa procesowego. Wymóg ten został expressis verbis wyartykułowany $\mathrm{w}$ art. $5 \S 1$ k.p.k. Trudno rozumieć wymóg udowodnienia winy w inny sposób niż jako konieczność udowodnienia wszystkich faktów uzasadniających twierdzenie, że oskarżony popełnił przestępstwo, w tym również okoliczności pozwalających przyjaćc zawinienie. Brak dowodu na tę okoliczność oznacza, że wina oskarżonego nie została udowodniona ${ }^{25}$. W konsekwencji wobec organu procesowego w zarysowanej powyżej sytuacji aktualizuje się nakaz, aby zachował się tak, jak zachowałyby się, gdyby składnikiem jego wiedzy było zdanie stwierdzające, iż oskarżony jest niewinny. W sytuacji podejmowania decyzji merytorycznej oznacza to obowiązek uniewinnienia oskarżonego lub umorzenia postępowania.

Jeżeli teraz przyjmiemy, że materialnoprawne domniemanie winy ma charakter prawny, to z przepisów prawa należy odkodować normę prawna, która leży u jego podstaw. Twierdzi się, że domniemanie to ma charakter materialny, ponieważ jego przesłanką jest udowodnienie oskarżonemu sprawstwa czynu zabronionego ${ }^{26}$, oraz wzruszalny, domniemanie bowiem upada wskutek udowodnienia okoliczności wyłączającej winę ${ }^{27}$. Takie ujęcie domniemania

S. Pawelec, op. cit., s. 1613; A. Tęcza-Paciorek, op. cit., s. 145, 158 i 177. W literaturze można wskazać także odmienne ujęcia, np. A. Murzynowski (Istota i zasady procesu karnego, Warszawa 1994, s. 255) wyłącza z tego zestawu prawo do milczenia. Niekiedy zasadę domniemania niewinności, onus probandi i regułę in dubio traktuje się jako równorzędne, powiązane ze sobą zasady. Zob. T. Grzegorczyk, J. Tylman, op. cit., s. 134.

${ }^{25}$ Powstaje także pytanie, jakie okoliczności można byłoby domniemywać. Jeżeli przyjąć, że tylko te, które zostały sformułowane w przepisach w sposób negatywny, to zakres domniemania byłby bardzo szeroki, obejmowałby domniemanie bezprawności czynu, jego karygodności, a także negatywnych znamion czynu zabronionego. Ponadto należy zaznaczyć, że żaden z przytoczonych argumentów nie stoi na przeszkodzie udowadnianiu poszczególnych przesłanek odpowiedzialności karnej poza postępowaniem karnym. Zob. W. Wróbel, O dwóch..., s. 327.

26 Ibidem, s. 246.

27 Autorzy przyjmujący domniemanie materialnokarnej winy wskazuja, że w odpowiednim zakresie domniemanie to ulega uchyleniu już w chwili pojawienia się racjonalnej wątpliwości co do wystapienia konkretnej okoliczności wyłączającej winę. Zob. ibidem, s. 252. Jednakże w literaturze teoretycznoprawnej wskazuje się, że charakterystyczną cechą domniemań prawnych jest przeniesienie ciężaru dowodu. W rezultacie w razie udowodnienia przesłanki domniemania, 
oznacza, że może ono mieć zastosowanie jedynie w toku postępowania dowodowego. W konsekwencji jest ono kierowane do organów prowadzacych postępowanie karne. Sa one adresatem normy, która nakazuje w przypadku udowodnienia oskarżonemu sprawstwa czynu zabronionego i nieprzeprowadzenia dowodu na okoliczność wyłączająca winę, aby zachowały się tak, jak zachowałyby się, gdyby składnikiem ich wiedzy było zdanie stwierdzające zachodzenie przesłanek zawinienia. W sytuacji wyrokowania oznacza to, przy zastrzeżeniu spełnienia innych przesłanek odpowiedzialności karnej, obowiązek stwierdzenia winy oskarżonego, tj. wydania wyroku skazującego, ewentualnie warunkowego umorzenia postępowania.

Powyższe podejście oznacza, że art. $1 \S 3 \mathrm{k} . \mathrm{k}$. stanowi przepis brany pod uwage nie tylko przy dekodowaniu normy sankcjonujaccej, lecz także normy o powyższej treści. Taka norma wchodzi w kolizję z zasadą statuowaną w art. 5 $\S 1$ k.p.k., gdy w postępowaniu nie przeprowadzono dowodu ani na karnomaterialną winę, ani na okoliczność wyłączająca tę winę, a zachodzą pozostałe przesłanki odpowiedzialności karnej. Pierwsza z tych norm nakazywałaby postapić tak jak w sytuacji, w której składnikiem wiedzy organu było zdanie stwierdzajace zachodzenie przesłanek zawinienia, co oznaczałoby stwierdzenie winy w rozumieniu prawa procesowego. Druga z tych norm nakazywałaby, aby organ zachował się tak, jak zachowałyby się, gdyby składnikiem jego wiedzy było zdanie stwierdzające, że oskarżony jest niewinny. Ponadto konsekwencją obowiązywanie pierwszej z norm, tym razem już w całym zakresie jej zastosowania, byłoby przerzucenie na oskarżonego ciężaru dowodu w kwestii zachodzenia okoliczności wyłączających winę, co oznaczałoby ograniczenie zakresu zastosowania gwarancji procesowych wywodzonych z zasady domniemania niewinności. Uprawniony jest więc wniosek, że zastosowanie tej zasady uległoby ograniczeniu w odniesieniu do przesłanek zawinienia.

W polskiej literaturze pogląd o zawężeniu zakresu zastosowania gwarancji wynikających z zasady domniemania niewinności w następstwie sposobu sformułowania przesłanki zawinienia w art. $1 \S 3 \mathrm{k} . \mathrm{k}$. wyraził Tomasz Kaczmarek $^{28}$. Takie stanowisko zają także Jerzy Lachowski, wskazując jednakże, że niektóre korzystne dla oskarżonego rozwiązania prawne wynikające $\mathrm{z}$ tej zasady znajdą zastosowanie na mocy innych przepisów ${ }^{29}$.

Zdecydowana większość przedstawicieli polskiej nauki prawa ${ }^{30}$ sprzeciwia się przerzucaniu na oskarżonego materialnego ciężaru dowodu okoliczności wyłączającej winę w rozumieniu prawa materialnego oraz przyjmuje, że wszelkie w tym zakresie wątpliwości należy rozstrzygać na rzecz oskarżonego, przy czym uznaja, że reguły in dubio pro reo oraz onus probandi stanowią konsekwencje obowiązywania zasady domniemania niewinności lub są z tą zasada

podmiot kwestionujacy fakty stanowiące przedmiot wniosku domniemania musi przeprowadzić dowód przeciwieństwa, czyli wykazać negację wniosku, a nie tylko zasiać wątpliwości co do faktów wskazanych we wniosku. Zob. L. Morawski, op. cit., s. 92; W. Patryas, op. cit., s. 66-67.

${ }^{28}$ T. Kaczmarek, op. cit., s. 170.

${ }^{29}$ J. Lachowski, op. cit., s. 664.

${ }^{30}$ W. Wróbel, $O$ domniemaniach..., s. 246, 252; idem, $O$ dwóch aspektach..., s. 823; P. Kruszyński, S. Pawelec, op. cit., s. 1632-1633; A. Murzynowski, op. cit., s. 270-271; A. Tęcza-Paciorek, op. cit., s. 170. 
ściśle związane. W konsekwencji zakładają że również przesłanka zawinienia jest objęta zasadą domniemaniem niewinności. Sprzeciw wobec ograniczenia zastosowania zasady domniemania niewinności wynika ze względów aksjologicznych ${ }^{31}$. Zasada domniemania niewinności ma fundamentalne znaczenie w państwie prawa, w którym określa charakter relacji państwo - obywatel: państwo zakłada, że obywatel jest osoba godna zaufania, rzetelnie realizująca nałożone na niego obowiązi ${ }^{32}$. Ponadto w literaturze wskazuje się, że oskarżony ma spore trudności w zdobyciu dowodów wykazujących okoliczność wyłączającą winę, a niekiedy jest to niemożliwe. Podkreśla się także przewagę organizacyjną i materialną organów prowadzących postępowanie nad oskarżonym ${ }^{33}$. Powyższe względy przemawiaja przeciwko ograniczeniu zakresu zastosowania zasady domniemania niewinności, a w rezultacie sprzeciwiaja się przyjęciu, że domniemanie winy $\mathrm{w}$ rozumieniu prawa materialnego jest domniemaniem prawnym.

\section{KONSEKWENCJE UJMOWANIA DOMNIEMANIA ZAWINIENIA JAKO DOMNIEMANIA FAKTYCZNEGO}

\section{Domniemanie zawinienia jako domniemanie faktyczne opierające się na uznaniu wyższości reguły nad wyjątkiem}

Istnienie przesłanki zawinienia jest więc objęte zasadą domniemania niewinności, z tym zastrzeżeniem, że w jej przypadku sposób funkcjonowania tej zasady jest „nieco odmienny” ${ }^{34}$. Owa odmienność wynikałaby z domniemania zachodzenia okoliczności umożliwiających stwierdzenie zawinienia. Takie domniemanie może mieć jednak wyłącznie charakter faktyczny. Ponadto posłużenie się takim domniemaniem nie naruszy zasady domniemania niewinności jedynie wówczas, gdy wskutek odwołania się do niego będzie można uznać za udowodnione okoliczności uzasadniające przypisanie materialnokarnej winy ${ }^{35}$.

$\mathrm{W}$ procesie karnym dowodzenie jest określonego rodzaju rozumowaniem, polegającym na wykazywaniu za pomocą środków dowodowych i odpowiedniej argumentacji prawdziwości twierdzeń o istnieniu bądź nieistnieniu określonych faktów. Pamiętać należy, że jest to zawsze rozumowanie probalistyczne, niepozwalające uzyskać pewności co do wyników procesu dowodzenia. W literaturze wskazuje się, iż twierdzenie o zachodzeniu określonej okoliczności jest udowodnione wówczas, gdy o jego prawdziwości jest przekonany podmiot dokonujący ustaleń faktycznych, jeżeli jednocześnie jest on w stanie przedstawić dowody na tak wysokie ich prawdopodobieństwo, że twierdzenie o ich zachodzeniu uzna każdy przeciętnie rozumujący człowiek ${ }^{36}$.

${ }^{31}$ Zob. A. Tęcza-Paciorek, op. cit., s. 46-54; P. Kruszyński, S. Pawelec, op. cit., s. 1569-1570.

32 A. Murzynowski, op. cit., s. 249

33 P. Kruszyński, op. cit., s. 100.

${ }^{34}$ W. Wróbel, $O$ dwóch aspektach..., s. 823.

35 T. Grzegorczyk, J. Tylman, op. cit., s. 415

${ }^{36}$ Zob. ibidem, M. Cieślak, op. cit., s. 50 i 52; A. Gaberle, Dowody w sqdowym procesie karnym. Teoria i praktyka, Warszawa 2010, s. 27-28. 
W nauce procesu karnego przyjmuje się, że domniemanie faktyczne jest pewnym założeniem (sądem) o istnieniu lub braku pewnych okoliczności, który to są uznajemy za prawdziwy w chwili spełnienia się określonych warunków. Również domniemanie faktyczne opiera się na regule, jednakże w przeciwieństwie do domniemania prawnego nie jest to norma prawna, lecz reguła doświadczenia życiowego, która pozwala z pewnym prawdopodobieństwem łączyć określone okoliczności (fakt lub zespół faktów) z faktem stanowiącym przedmiot domniemania. Domniemanie faktyczne może zostać podważone $\mathrm{w}$ toku postępowania dowodowego ${ }^{37}$.

Domniemanie faktyczne służy ustalaniu faktów. Oznacza to, że podstawą domniemania oraz wnioskiem domniemania winny być określone fakty. Jeżeli tak, to faktem domniemywanym jest okoliczność, iż oskarżony był $\mathrm{w}$ stanie sensownie autodeterminować swoje zachowanie w czasie popełnienia czynu, a w konsekwencji miał możliwość wyboru zachowania zgodnego z prawem. Zachodzenie takiej możliwości jest generalna przesłanką postawienia sprawcy czynu zabronionego zarzutu, czyli stwierdzenia jego prawnomaterialnej winy ${ }^{38}$. Pojęcie zarzutu i winy sa już jednak terminami szeroko rozumianego języka prawnego. Przypisanie winy następuje wskutek subsumcji ustalonych okoliczności faktycznych pod przepis prawa. Domniemywanie zdolności sensownej autodeterminacji zachowania jest równoznaczne z domniemywaniem, że nie zachodzi jakakolwiek okoliczność, która by ją wyłączała. Większe problemy wiążą się z określeniem podstawy domniemania: doświadczenie życiowe pozwala łączyć możliwość sensownej autodeterminacji zachowania nie tyle ze sprawstwem czynu zabronionego, lecz z cechami przypisywanymi jego sprawcy. Zakłada się, że dorosły człowiek jest zdolny do sensownego pokierowania swoim zachowaniem. Za przesłankę domniemania mogłoby więc służyć wykazanie, że oskarżony jest człowiekiem oraz że w chwili popełnienia czynu osiagnął odpowiedni wiek (art. 10 k.k.). W procesie co do zasady nie prowadzi się dowodu na powyższe okoliczności, uznając ich oczywistość, a to oznacza, że w przypadku dorosłych oskarżonych mamy do czynienie z domniemaniem faktycznym zbliżonym w swojej konstrukcji do domniemania formalnego.

Tak skonstruowane domniemanie opiera się na uznaniu wyższości reguły (możliwość sensownej autodeterminacji zachowania w chwili popełnienia czynu) nad wyjątkiem (okoliczność wyłączająca winę). W konsekwencji takie domniemanie jest zgeneralizowanym założeniem przyjętym a priori przez organy prowadzace postępowanie karne. W literaturze procesowej wskazuje się, że zachodzenie domniemywanego faktu ustala się bez jego udowodnienia ${ }^{39}$. Domniemanie zawinienia upada albo w następstwie zakwestionowania twierdzenia o niezachodzeniu okoliczności wyłączających winę lub powstania co do

${ }^{37}$ Ibidem, s. 33; M. Cieślak, op. cit., s. 56-58; J. Nelken, Domniemania..., s. 1591-1592 i 1605.

${ }^{38}$ W. Wróbel, A. Zoll, op. cit., s. 332.

${ }^{39}$ Tak J. Nelken, Domniemania..., s. 1592, 1605; P. Kruszyński, op. cit., s. 41-48; W. Daszkiewicz, op. cit., s. 248; M. Cieślak, Zagadnienia..., s. 55; T. Grzegorczyk, J. Tylman, op. cit., s. 419; A. Tęcza-Paciorek, op. cit., s. 61. 
tego twierdzenia racjonalnych wątpliwości ${ }^{40}$, albo wskutek udowodnienia okoliczności wyłączającej winę ${ }^{41}$.

Odwołanie się do tak rozumianego domniemania faktycznego zawinienia nie spełnia więc wymogu udowodnienia, o którym mowa w art. $5 \S 1$ k.p.k. $\mathrm{Z}$ zasadą domniemania niewinności jest sprzeczny zwłaszcza postulat udowodnienia okoliczności wyłączającej winę, jest on bowiem równoznaczny z przerzuceniem materialnego ciężaru dowodu na oskarżonego.

\section{Domniemanie zawinienia jako domniemanie faktyczne konstruowane w sposób zbliżony do dowodu poszlakowego}

W literaturze wyrażono pogląd, iż w związku brakiem możliwości przeprowadzenia pozytywnego dowodu na zachodzenie okoliczności uzasadniających przypisanie winy karnomaterialnej, przesłankę tę należy przyjąć bez udowodnienia, chyba że ujawni się okoliczność wskazująca na odmienny wniosek. Dopiero wówczas ustalenie przesłanki zawinienia zostaje objęte procesowa zasadą domniemania niewinności ${ }^{42}$. Konsekwencji tej można jednak uniknaćc, o ile przy ustaleniu zawinienia odwołamy się do domniemania faktycznego konstruowanego w sposób zbliżony do dowodu poszlakowego ${ }^{43}$. Takie domniemanie stanowiłoby przykład dowodu pośredniego ${ }^{44}$. W przypadku tak rozumianego domniemania faktycznego w pełni znajduje zastosowanie zasada swobodnej oceny dowodów, wniosek domniemania może zostać odrzucony, o ile tylko zebrany materiał dowodowy go nie potwierdza lub też istnieje możliwość innej interpretacji materiału dowodowego. W konsekwencji oskarżony kwestionujaccy wniosek wypływający z domniemania nigdy nie jest obarczony materialnym ciężarem dowodu ${ }^{45}$.

Sąd może stwierdzić winę oskarżonego (w rozumieniu prawa procesowego), gdy nie budzi ona wątpliwości. Oznacza to przede wszystkim konieczność udowodnienia, że oskarżony jest sprawcą czynu zabronionego, tj. iż zachowanie oskarżonego wyczerpało jego przedmiotowe i podmiotowe znamiona. Są będzie więc obowiązany zbadać świadomość sprawcy w chwili czynu i jego nastawienie wolicjonalne. W konsekwencji sąd zainteresuje się sposobem postrzegania przez oskarżonego otaczającej go rzeczywistości, jego sposobem ro-

\footnotetext{
${ }^{40}$ Np. J. Nelken, Domniemania..., s. 1605; P. Kruszyński, op. cit., s. 100-101; W. Wróbel, O domniemaniach..., s. 252.

${ }^{41}$ M. Cieślak, Polska procedura karna, w: S. Waltoś (red.), Marian Cieślak. Dzieła wybrane, t. 2, Kraków 2011, s. 284.

${ }^{42}$ W. Wróbel, O domniemaniach..., s. 251-252. Zob. także D. Świecki, op. cit., s. 8-9.

${ }_{43}$ Jest to najstarsza koncepcja domniemania faktycznego, przyjmowana przez polski SN. Zob. L. Morawski, op. cit., s. 98-100.

${ }^{44}$ Tak, zdaję się, A. Gaberle, op. cit., s. 34-35. Warto wskazać, że zdaniem cywilistów: „Domniemanie faktyczne jest środkiem dowodowym. Jest ściśle związane z odrzuceniem legalnej teorii dowodów i zastapieniem jej - jako zasady - swobodna oceną dowodów. Z tej też racji domniemanie faktyczne podlega konstruowaniu także $\mathrm{z}$ uwzględnieniem reguł $\mathrm{z}$ art. 233 § 1 k.p.c. Jest ono z reguły wynikiem braku bezpośrednich środków dowodowych. Stanowi sąd kategoryczny o fakcie, nie ma natomiast charakteru tylko hipotezy". K. Piasecki, Komentarz do art. 231 k.p.c., w: K. Piasecki, A. Marciniak (red.), Kodeks postępowania cywilnego, t. 1, Warszawa 2014, teza 1.

${ }^{45}$ Zob. L. Morawski, op. cit., s. 99-100.
} 
zumowania, motywacją. Bez zgłębienia tych okoliczności nie sposób bowiem racjonalnie wypowiedzieć się co do umyślności/nieumyślności czynu. Zbadanie motywacji oraz sposobu i okoliczności popełnienia czynu jest konieczne także ze względu na potrzebę dokonania oceny stopnia szkodliwości społecznej (art. $115 \S 2$ k.k.). Przy wymiarze kary sąd jest zobowiązany uwzględnić obok ww. okoliczności także właściwości i warunki osobiste sprawcy (art. 53 $\S 2$ k.k.). Wszelkie te okoliczności sąd ma obowiązek dogłębnie zbadać. Łatwo zauważyć, że jeżeli zachodzą okoliczności wyłączające winę, organ winien zaobserwować fakty uprawdopodabniajace ich wystapienie, np. patologiczne postrzeganie przez oskarżonego rzeczywistości lub odstająca od normy motywację, nietypowy lub szczególnie drastyczny sposób popełnienia czynu, które to okoliczności wskazują na możliwość choroby psychicznej. Badając motyw, sąd może ustalić, że oskarżony popełnił czyn, gdyż nie wiedział, że jest on bezprawny (błąd co do bezprawności), lub błędnie przyjął, że zachodzi kontratyp albo że oskarżony dział pod presja, pod wpływem emocji lub w celu ratowania innego dobra (szczególna sytuacja motywacyjna). Dodać należy, że rzetelnie przeprowadzony proces karny zakłada także bezpośredni kontakt organu prowadzącego postępowanie z oskarżonym, który powinien pozwolić na wyrobienie sobie przez organ zdania w kwestii zdolności oskarżonego do sensownego pokierowania swoim zachowaniem. Istotny będzie także fakt, iż racjonalnie prowadzący swoją obronę oskarżony nie podnosi wystapienia okoliczności niepozwalajacej mu na pokierowanie swoim zachowaniem.

Tak więc $\mathrm{w}$ toku postępowania organ poczyni ustalenia $\mathrm{w}$ zakresie okoliczności dotyczących samego czynu, okoliczności, w których popełniono czyn, oraz właściwości sprawcy. Okoliczności te będą także nieść informację w kwestii zdolności oskarżonego do pokierowania swoim zachowaniem. Co więcej, badając te okoliczności, organ poczyni także spostrzeżenia, czy zachodzą wątpliwości co do istnienia okoliczności wyłączających tę zdolność. Jeżeli taka okoliczność zachodzi, to wedle dużego prawdopodobieństwa powinna ona pozostawić ślad w zebranym materiale dowodowym, który wzbudzi wątpliwość sądu. W przypadku ich braku organ będzie uprawniony do wnioskowania o możliwości oskarżonego do sensownego pokierowania swoim zachowaniem w czasie popełnienia czynu w oparciu o doświadczenie życiowe wskazujące, że ludzie o właściwościach sprawcy z wysokim prawdopodobieństwem sa w stanie sensownie autodeterminować swoje zachowanie mające właściwości czynu zarzuconego sprawcy i popełnione w okolicznościach takich samych jak te, w których popełniono zarzucony oskarżonemu czyn. Takie wysokie prawdopodobieństwo będzie prowadziło do subiektywnego przekonania organu o zachodzeniu przesłanki zawinienia, a przeprowadzone rozumowanie będzie służyło jej udowodnieniu.

W przeciwieństwie do domniemania faktycznego wynikającego z uznania wyższości reguły nad wyjątkiem, nie mamy tutaj do czynienia z założona a priori zdolnościa oskarżonego do pokierowania swoim zachowaniem przyjęta w oparciu o bardzo ogólne założenia antropologiczne. Wniosek taki rodzi się $\mathrm{w}$ trakcie postępowania dowodowego, jest oparty na czynionych w tym postępowaniu ustaleniach co do okoliczności czynu, właściwości czynu i sprawcy 
(przy czym okoliczności te powinny być wykazane środkami dowodowymi) oraz na tym, czego postępowanie dowodowe nie ujawniło, a co wedle wszelkiego prawdopodobieństwa winno się ujawnić, tj. o brak śladów zachodzenia okoliczności wyłączających winę ${ }^{46}$. Pojawienie się wątpliwości w tym zakresie oznacza możliwość innej interpretacji materiału dowodowego. Wątpliwość tę należy usunąć przez przeprowadzenie dowodu w przedmiocie niezachodzenia okoliczności wyłączającej winę lub rozstrzygnąc ją na korzyść oskarżonego. W powyższym ujęciu domniemanie faktyczne jest więc rezultatem oceny materiału dowodowego, a nie sądem organu przystępującego do tej oceny, oraz opiera się na regule doświadczenia życiowego uwzględniającej wszelkie okoliczności ujawnione w danej sprawie.

W literaturze procesowej kwestionuje się utożsamianie dowodu poszlakowego z domniemaniem faktycznym, mimo dostrzeżenia, że w obu przypadkach organ opiera się na indukcji statystycznej, która prowadzi do przekonania o „normalności” związku pomiędzy określonymi stanami rzeczy ${ }^{47}$. Twierdzi się, że domniemanie faktyczne różni się od dowodu poszlakowego oparciem wnioskowania na wyizolowanym fakcie ustalonym $\mathrm{w}$ sprawie i nie spełnia wymogu eliminacji hipotez konkurencyjnych ${ }^{48}$. Do ustalonego powyżej schematu pierwsze spostrzeżenie nie znajduje zastosowania. Co do drugiego - to konieczność eliminacji wersji konkurencyjnej powstaje, jeżeli racjonalnie należy przyjąć możliwość jej zajścia. Jak łatwo zauważyć, w przypadku ustalania przesłanki zawinienia, taka wersja rysuje się dopiero w chwili pojawienia się wątpliwości co do zachodzenia okoliczności wyłączającej winę. Dopóki wątpliwość nie zostanie usunięta wskutek przeprowadzenia odpowiedniego dowodu, nie można wnioskować o zdolności oskarżonego do sensownego pokierowania swoim czynem.

\section{PODSUMOWANIE}

W procesie karnym można odwołać się do domniemania faktycznego zachodzenia przesłanki zawinienia konstruowanego na wzór dowodu poszlakowego zgodnie z zasadą swobodnej oceny dowodów (art. 7 k.p.k.). Jeżeli wymogi statuowane przez zasadę swobodnej oceny dowodów zostaną spełnione, tak rozumiane domniemanie powoduje przełamanie domniemania niewinności. Podstawą konstruowania domniemania zawinienia w przypadku udowodnienia oskarżonemu sprawstwa czynu zabronionego jest więc art. 7 k.p.k., a nie art. $1 \S 3 \mathrm{k} . \mathrm{k}$.

Domniemanie zawinienia w powyższym ujęciu jest instytucją prawa procesowego, a nie materialnego. Negatywne ujęcie przesłanki zawinienia w art. 1 $\S 3$ k.k. odzwierciedla co prawda przekonanie ustawodawcy o generalnej zdol-

${ }^{46}$ Brak określonej okoliczności, np. alibi, może stanowić poszlakę obciążająca. T. Grzegorczyk, J. Tylman, op. cit., s. 417.

47 Zob. ibidem, s. 420; J. Nelken, Domniemania..., s. 1606-1607; idem, Dowód poszlakowy $w$ procesie karnym, Warszawa 1970, s. 151-153.

48 L. Morawski, op. cit., s. 99. 
ności człowieka do autodeterminancji swojego zachowania, można więc mówić o domniemaniu - założeniu, przyjętym przez ustawodawcę, które wyjaśnia sposób skonstruowania przepisu. Brak jest jednak podstaw do twierdzenia o ustanowieniu domniemania winy $\mathrm{w}$ prawie karnym. Sposób sformułowania art. $1 \S 3$ k.k. nie jest jednak bez znaczenia dla organu prowadzącego postępowanie. W ten sposób ustawodawca opowiedział się w sporze między determinizmem i indeterminizmem po stronie osób przyjmujacych istnienie wolnej woli. Przekonanie o posiadaniu przez człowieka wolnej woli odpowiada codziennemu doświadczeniu, było jednak kwestionowane w nauce. Spór z trudem poddawał się rozstrzygnięciu na podstawie danych empirycznych, w znacznej mierze ma charakter filozoficzny. Na pewno nie mógłby zostać rozstrzygnięty na podstawie danych zgromadzonych na rozprawie ${ }^{49}$. Można więc twierdzić, że takie sformułowanie przepisu zwalnia sąd z konieczności uzasadniania generalnego założenia o zdolności człowieka do kierowania swoim zachowaniem. Ponadto sformułowanie przepisu legitymizuje badanie przesłanki zawinienia od strony negatywnej ${ }^{50}$. Doświadczenie życiowe uzasadni sformułowanie wniosku o zachodzeniu przesłanki zawinienia, jeżeli wszechstronne zbadanie okoliczności konkretnej sprawy nie nasunie watpliwości co do wystapienia chociażby jednej okoliczności wyłączającej winę albo po wykluczeniu takich wątpliwości. Takie postawienie sprawy ukierunkowuje czynności w postępowaniu dowodowym: ich celem jest poszukiwanie śladów zaistnienia okoliczności wyłączających winę. Mając powyższe na względzie, możemy mówić o badaniu przesłanki zawinienia od strony negatywnej.

dr Andrzej Jezusek

adwokat

biuro@jezusekkancelaria.pl

\section{'PRESUMPTION OF GUILT' IN SUBSTANTIVE CRIMINAL LAW AND THE PROCEDURAL PRESUMPTION OF INNOCENCE}

Sum mary

The article elaborates on 'presumption of guilt.' The term 'guilt' has different meanings in substantive criminal law and procedural criminal law. However, the presumption of guilt in substantive criminal law ought not lead to a violation of the procedural presumption of innocence. Therefore, it shall be understood as a presumption of fact which must meet all the requirements referred to in Article 7 of the Code of Criminal Procedure or, in other words, be regarded as indirect evidence. For this reason, there is no legal basis to contend that the presumption of guilt rule has been established under substantive criminal law. Negative conceptualisation of guilt in the Penal Code is an expression of legislator's conviction that human beings are generally able to control their conducts. So we can only talk about a presumption, a premise adopted by legislature, which explains the construction of the provision analysed.

\footnotetext{
${ }^{49}$ W. Wróbel, O domniemaniach..., s. 247; T. Kaczmarek, op. cit., s. 175.

${ }^{50}$ D. Świecki, op. cit., s. 8.
} 
